\title{
Determining Value in Informant Design with Children
}

\author{
Emanuela Mazzone \\ Child Computer Interaction Group \\ University of Central Lancashire \\ Preston (UK) \\ +44 1772895152 \\ EMazzone@uclan.ac.uk
}

\begin{abstract}
This research looks at design methods for children technologies. It takes a User-Centred Design approach, where the involvement of the users is essential to the achievement of satisfactory products.
\end{abstract}

\section{Categories and Subject Descriptors}

H 5.2 [User Interfaces]: Prototyping. User-Centred Design, Evaluation/methodology

\section{General Terms}

Performance, Design, Experimentation, Human Factors, Theory.

\section{Keywords}

Informant design, children users, design methods, value for participants.

\section{THE RESEARCH PROBLEM}

Previous and ongoing research in the field has proved the practice of engaging users in designing interactive products to be successful in minimising the risk of producing artefacts that would not meet the user requirements. This approach is considered even more needed when the users are children as user requirements are more likely to be mistaken from adult designers only. It has however some costs; it is time consuming to plan and effect, careful planning is needed and analysis of findings is complex. Despite the difficulties in accessing the users and managing the design stages according to them, this practice has been proved to have positive impact on the design product but also on the participant.

One of the many examples is the 'Kidstory' project, where a team of designers, researchers and children successfully worked together to develop innovative IT tools to support collaborative storytelling activities [1]. The researchers conducted an evaluation both consulting the teachers and the children's own documentation of the sessions. The results showed that the

\footnotetext{
(c) The Author 2008.
}

Published by the British Computer Society whole design process was important to strengthen the children's identity as inventors, and, during the whole project, the pupils clearly improved their narrative skills as story-tellers and their understanding and handling of technology. In the so called design-centred learning, Druin [3] identifies five main learning outcomes while working with children, as all the members of the design team can learn: team working and collaboration, respect for design partners, contents about the design topic, technology skills, and the design process itself.

Nesset and Large [7] provide an extended review of projects that involved children since early stages of the design and in the generation of design concepts. They conclude that, although participatory design techniques can often be expensive and time consuming when working with users, the advantages in terms of innovation and appropriateness of design can outweigh these negative factors. Therefore, "the real issue would seem to be not whether involving children is good or bad but rather how to more effectively engage them in the design process" (Ibid). This statement shifts the focus on the methods used to involve children and how to achieve value from doing it.

Research in the area also documents the positive effect of the use of ICT on young users [2]. In particular, amongst hard-toreach pupils, positive impacts of the use of ICT for educational purposes are reported in terms of motivation, attendance and behaviour $[8,9]$.

What emerged from the literature is the multitude of benefits at different levels according to the different stakeholders' perspectives. This suggested the need for a deeper understanding of the benefits resulting from each approach for different design contexts and different participants, in order to be able to optimise the outcomes of the design activity.

\section{CONTRIBUTION TO HCI FIELD}

The present research work explores different methods and techniques of involving children users in design sessions as informant designers and it aims at finding some methods of understanding the value of the design activities and a possible way to optimise this value. Two of the main expected contributions to the field will be:

- Definition of value for the different stakeholders for what concern the design process, not just the product.

- Understanding benefits of design methods and optimising the design sessions with children.

\section{METHODOLOGY}

I have conducted a set of small situated studies and two locally funded one year projects so far to investigate different design 
methods. In all the studies the users were considered more as informants [10] rather then design partners, being engaged in defined design activities over a limited amount of time. In this way the researcher has the role of facilitators during the design sessions by providing the children with instructions and resources for the design activities.

In the context of designing with children, the most common tendencies are to differentiate the levels of engagement and inputs contributed between informant design (ID) and cooperative enquiry (CE) $[3,10]$. In the first, ID, the children are considered native informants and experts of their practice and needs and they are consulted at crucial stages of the design process; in cooperative enquiry, children are regarded as part of the design team throughout the whole process and this usually implies a longer term commitment from both parties.

My previous studies [4, 5, 6 report on a few of them] have varied in design contexts, which differed in terms of the duration of the study, the design goals, the age range of the children involved, and the educational environment and background the children came from. In each case different techniques were adapted to suit the design conditions and the outcomes have been analysed to understand their usefulness in the design process.

\section{CURRENT STATUS}

The research up to now has helped in building a solid knowledge on how to structure and organise design sessions with users in different contexts and how to analyse the different elements that affect the results. Current studies are looking at measuring values in design activities that use different techniques, with respect to the design process as well as the participants' perceptions.

\section{INTERIM CONCLUSIONS}

In a study on disaffected teenagers [5] the emergent behavioural and attitude changes of the participants during the design sessions triggered the interest to define some methods to value the 'worthiness' of the design sessions for each of the stakeholders involved in the design sessions, the pupils, the tutors.

A deeper understanding of the effective benefits that can come out of this design practice is considered to be helpful to optimise its use and its value.

\section{FUTURE WORK}

A one year study is planned to start in September 2008 where the value in design activities will be further investigated and tested.

The study will be part of a project that aims to improve a portable music device for children and to explore how children will learn about music, share music and create opportunities to collaborate. The focus will be on children (age will vary from 4 to 11 years old) who are newly immigrant or with moderate learning disabilities, to see how they manage the technology and how it changes play and sociality. The first part of the project will be dedicated to engage children to evaluate the device prototype and the underlying technology for its ease of use and appeal; learn how children use the device; gather children's ideas for the improvement of the device; discover the impact the device will have on supporting collaborative activities and its potential in overcoming social difficulties.

This project will provide me with the context for studies over a 10 month period, where methods for determining value of the design process will be developed and validated.

\section{REFERENCES}

[1] Alborzi, H., A. Druin, J. Montemayor, M. Platner, J. Porteous (2000) Designing StoryRooms: Interactive Storytelling Places for Children. ACM SIGCHI 2000 Symposium on Designing Interactive Systems, Brooklyn, ACM Press. 95-104

[2] Condie, R. \& Munro, R. (2007) The impact of ICT in schools - a landscape review. Becta. [http://www.becta.org.uk/publications]

[3] Druin, A. (2002) The Role of Children in the Design of New Technology." Behaviour and Information Technology 21(1): 1 - 25.

[4] Kelly,R., Mazzone,E., Horton, P., Read, J. "Bluebells: A Design Method for Child-Centred Product Development". in Proceedings of NordiCHI 2006 (Oslo, 2006), ACM Press

[5] Mazzone, E., Read, J., Beale, B. (2008) Understanding Children's Contributions during Informant Design in Proceedings of British HCI 2008 (in press)

[6] Mazzone, E., Xu, D., Read, J. (2007) "Design in Evaluation: Reflections on Designing for Children's Technology" in Proceedings of the British HCI conference 2007, Lancaster, UK. ACM Press

[7] Nesset, V. and Large, A. (2004) Children in the information technology design process: A review of theories and their applications in Library \& Information Science Research 26 (2004) 140-161 Elsevier Inc.

[8] Passey, D., Rogers, C., Machell, J. and McHugh, G. (2004) The Motivational Effect of ICT on Pupils. DfES Research Series Ref No. RR 523. London: DfES

[9] Russell, T. \& McGuigan, L. (2007), An Exploration of Digital Creativity Used to Engage and Motivate 'Hard-toReach' Learners in Behavioural, Emotional and Social Difficulties (BESD) Schools. BECTA Research Report, UK

[10] Scaife, M., Y. Rogers, F. Aldrich \& M. Davies (1997). Designing For or Designing With? Informant Design for Interactive Learning Environments. CHI '97, Atlanta, ACM Press 